\title{
Last Subject In Date Time
}

National Cancer Institute

\section{Source}

National Cancer Institute. Last Subject In Date Time. NCI Thesaurus. Code C142596.

The date and/or date and time when the final participant in a clinical trial is enrolled. 